\title{
Cardiovascular Disease in Bangladesh: A Review
}

\author{
AKM Monwarul Islam, AKM Mohibullah, Timir Paul
}

\begin{abstract}
:
Like elsewhere, cardiovascular disease (CVD) is an increasingly important cause of morbidity and mortality in Bangladesh. Over the past few decades, because of epidemiological transition, the prevailing disease pattern in this country changed from predominantly communicable to predominantly non- communicable disease, CVD contributes to the latter a lot. Actually, CVD particularly coronary artery disease (CAD) is getting epidemic proportion day by day. Hypertension and heart failure are on the rise, whereas the prevalence of acute rheumatic fever is declining. However, despite some efforts, reliable data concerning various aspects of CVD is inadequate at present. The current prevalence of
\end{abstract}

hypertension, CAD, rheumatic fever and rheumatic heart disease and stroke may be $20-25 \%, 4-6 \%,<1 / 1000,0.3-$ $1.0 \%$ respectively. Besides conventional risk factors for different CVD, genetic predisposition and some novel issues like high salt intake, arsenicosis, hypovitaminosis $D$ and air pollution may play important role in the aetiopathogenesis of CVD in this population. Formulation of appropriate policy and more emphasis on preventive strategy may help combat CVD in Bangladesh.

Keywords: Coronary Artery Disease, Hypertension, Rheumatic Heart Diseases, Bangladesh.

(Bangladesh Heart Journal 2016; 31(2) : 80-99)

\section{Introduction:}

CVD is a major public health problem throughout the world. It is the number one cause of morbidity and mortality world-wide. The economic impact of different types of CVD is enormous. Traditionally, Bangladesh is a developing country burdened with communicable diseases. However, like many other low-income countries in the world, she has been experiencing epidemiological transition; the prevailing disease pattern is changing from communicable diseases to noncommunicable diseases (NCD). ${ }^{1,2}$ Small pox, once upon a time a regular epidemic, has been eradicated. Cholera is no longer a major threat to our health. The major causes of death in Bangladesh gradually shifted from acute

1. Assistant Professor, Department of Cardiology, Sir Salimullah Medical College, Dhaka, Bangladesh.

2. Professor, Department of Cardiology, BIRDEM General Hospital, Dhaka, Bangladesh.

3. Assistant Professor, Division of Cardiology, Director, Cardiovascular Research, Director Peripheral Intervention, Associate Director, Interventional Cardiology, Director, Cardiac Rehabilitation and Prevention. Quillen College of Medicine, East Tennessee State University, Johnson City, Tennessee, USA.

Address of Correspondence: Dr. AKM Monwarul Islam, Assistant Professor, Department of Cardiology, Sir Salimullah Medical College, Dhaka, Bangladesh. E-mail: drmonwarbd@yahoo.com infectious and parasitic diseases to NCDs. ${ }^{3}$ In 1986, NCDs represented only $8 \%$ of total deaths compared to $52 \%$ of deaths due to communicable diseases ${ }^{1}$, whereas in 2014, NCDs are estimated to account for $59 \%$ of total deaths; CVD is the single-most important contributor, and is responsible for $17 \%$ of total mortality 4 . Despite this paradigm shift, little is known regarding the epidemiological pattern and underlying pathophysiology of CVD in Bangladesh. Recognizing these limitations, the present review has been planned to compile the available data on this important public health issue. This review will make a basis for future research and would be a valuable source of information.

\section{Methods:}

Data was collected from the available articles searched via PubMed, Google Scholar and BanglaJOL supported by the International Network for the Availability of Scientific Publications up to December, 2016. Besides this, local journals which were not available online but recognized by the Bangladesh Medical and Dental Council were searched as well. Also, some information was collected from personal communication with responsible persons. 


\section{Epidemiology of CVD}

CVD is the number one killer worldwide. 5,6 According to the Heart Disease and Stroke Statistics - 2016 update by the American Heart Association, heart disease and stroke continue to be the top two killers worldwide. As of 2013 , $31 \%$ of all deaths were from CVD, with $80 \%$ occurring in low- and middle-income countries; stroke accounted for $11.8 \%$ of all deaths. The burden of CVD, especially the CAD is increasing at a greater rate in South Asia than in any other region globally. The prevalence of CVD in India has been estimated to be nearly 3\% in 2000 , and upto $10 \%$ in recent years, indicating rising prevalence. ${ }^{7,8}$ Also, data from the Registrar-General of India shows that CVD is the top killer of Indians, accounting for $23 \%$ of all deaths in 2010-2013 as compared to $20 \%$ in $2004-2006 .{ }^{9}$ Among the NCDs, CVD is probably the most important cause of mortality and morbidity in Bangladesh. In 2014, NCDs represented $59 \%$ of the total deaths; CVD was the single-most important contributor, being responsible for $17 \%$ of the country's deaths. ${ }^{4}$ According to the Health Bulletin $2015^{10}$, CVD and stroke together was the topmost cause of death in Upazila, District and Medical College Hospitals, and was responsible for $17.78 \%, 21.83 \%$ and $16.32 \%$ deaths respectively in 2014 . Also, stroke and acute myocardial infarction together was the topmost cause of admission of the indoor patients in Medical College Hospitals across the country in the same year. ${ }^{10}$

The exact prevalence of CVD in Bangladesh is not known. Probably the first attempt to determine the prevalence of heart disease was made by Malik et al. in a survey amongst 7062 people of different age groups in Dacca City and in a village; the surgery revealed the prevalence of $2.92 \%{ }^{11}$ Self-reported prevalence of heart disease among the 25 to 64 -year-old respondents were $5.3 \%$ to $66.3 \%$ in males and $7.8 \%$ to $77.7 \%$ in females in another study in $2005 .{ }^{12}$ The wide range of prevalence is presumably due to differences in study design and methodology.

The prevalence of CAD in Bangladesh has been reported to be $0.33 \%$ to $19.6 \%$ in different studies. ${ }^{11,13-6}$ (Table 1 ). Despite marked disparity in values, there seems to be a rising prevalence and mortality from CAD. ${ }^{1,16}$ A recent study from rural Bangladesh demonstrated a dramatic increase in CVD, and the age-standardized CVD mortality increased by 30 -fold (from 16 deaths per 100,000 to 483 deaths per 100,000) among males and 47-fold (from 7 deaths per 100,000 to 330 deaths per 100,000) in females. ${ }^{1}$

Like CAD, hypertension is an increasingly important medical and public health problem in Bangladesh. The reported prevalence varies widely from $1.21 \%$ to $32 \% .{ }^{11,16,18-35}$ (Table 2). According to the Bangladesh NCD Risk Factor Survey 201027, the prevalence of hypertension is $17.9 \%$ in general, $18.5 \%$ in men and $17.3 \%$ in women. On the other hand, overall, agestandardized prevalence of prehypertension and hypertension were 27.1 and $24.4 \%$, respectively, in a recently published analysis based on the nationwide population-based 2011 Bangladesh Demographic and Health Survey (BDHS) ${ }^{29}$. Even higher prevalence of hypertension of $40 \%$ (95\% confidence interval $(\mathrm{Cl}) 38$ $42 \%$ ) was found in a population-based study involving 3096 adults aged $>30$ years from rural Bangladesh. ${ }^{33} \mathrm{~A}$ recently-published meta-analysis concerning risk factors for CVD in Bangladesh found the prevalence of hypertension to be $15.1 \%{ }^{34}$

Table-I

Prevalence of coronary artery disease in Bangladesh.

\begin{tabular}{|c|c|c|c|c|c|c|c|}
\hline Reference & Year & Place & $\begin{array}{l}\text { Age, } \\
\text { year }\end{array}$ & Diagnostic criteria & $\begin{array}{c}\text { No. } \\
\text { screened }\end{array}$ & $\begin{array}{c}\text { Prevalence } \\
(\%)\end{array}$ & $\begin{array}{c}\text { Type of } \\
\text { study }\end{array}$ \\
\hline Malik $A^{11}$ & 1976 & $\begin{array}{l}\text { Urban and } \\
\text { rural }\end{array}$ & $15-74$ & ECG, chest X-ray & 7062 & 0.33 & $\begin{array}{l}\text { Cross } \\
\text { sectional }\end{array}$ \\
\hline $\begin{array}{l}\text { Zaman, } \\
\text { et al. }{ }^{13}\end{array}$ & 2007 & Rural & $>20$ & $\begin{array}{l}\text { Pathological Q } \\
\text { wave or current } \\
\text { medication }\end{array}$ & 447 & $\begin{array}{l}3.4 \text {;male } 4.6, \\
\text { female } 2.7\end{array}$ & $\begin{array}{l}\text { Cross } \\
\text { sectional }\end{array}$ \\
\hline Ahsan et al. $^{14}$ & 2009 & $\begin{array}{l}\text { Urban; } \\
\text { UGC } \\
\text { Employee }\end{array}$ & $\begin{array}{l}\text { Mean } \\
\text { age } \\
44.8\end{array}$ & $\begin{array}{l}\text { Not defined; ECG and } \\
\text { echo were used }\end{array}$ & 163 & 20.9 & $\begin{array}{l}\text { Cross } \\
\text { sectional }\end{array}$ \\
\hline $\begin{array}{l}\text { Sayeed et } \\
\text { al. }^{15} \text { en }\end{array}$ & 2010 & Rural & $\geq 20$ & $\begin{array}{l}\text { 1) H/o angina plus } \\
\text { ECG +ve; } \\
\text { 2)post-MI with } Q \text { or } \\
\text { non-Q MI; } \\
\text { 3) diagnosis by a } \\
\text { cardiologist. }\end{array}$ & 768 & 1.85 & $\begin{array}{l}\text { Cross } \\
\text { sectional }\end{array}$ \\
\hline Parr et al. ${ }^{16}$ & 2011 & $\begin{array}{l}\text { Urban and } \\
\text { rural }\end{array}$ & $>25$ & Self-reported & 8591 & $\begin{array}{ll}5.1 ; & \\
\text { urban } & 6.0, \\
\text { rural } 4.7 & \end{array}$ & $\begin{array}{l}\text { Cross } \\
\text { sectional }\end{array}$ \\
\hline
\end{tabular}

UGC: University Grants Commission 
Table-II

Prevalence of hypertension in Bangladesh.

\begin{tabular}{|c|c|c|c|c|c|c|c|}
\hline Reference & Year & Place & $\begin{array}{l}\text { Age, } \\
\text { year }\end{array}$ & $\begin{array}{c}\text { Diagnostic criteria } \\
\text { (BP in } \mathrm{mmHg} \text { ) }\end{array}$ & $\begin{array}{c}\text { No. } \\
\text { screened }\end{array}$ & $\begin{array}{c}\text { Prevalence } \\
(\%)\end{array}$ & $\begin{array}{l}\text { Type of } \\
\text { s }_{\text {tudy }}\end{array}$ \\
\hline Malik $A^{11}$ & 1976 & $\begin{array}{l}\text { Urban and } \\
\text { rural }\end{array}$ & $15-74$ & Not mentioned & 7062 & 1.21 & $\begin{array}{l}\text { Cross } \\
\text { sectional }\end{array}$ \\
\hline Ullah W..$^{{ }^{8}}$ & 1976 & Rural & $>20$ & Not mentioned & 17569 & 2.6 & $\begin{array}{l}\text { Cross } \\
\text { sectional }\end{array}$ \\
\hline Islam et al. ${ }^{19}$ & 1983 & Rural & & $\mathrm{dBP}>90$ & 5026 & 6.70 & $\begin{array}{l}\text { Cross } \\
\text { sectional }\end{array}$ \\
\hline Sayeed et al. ${ }^{20}$ & 1994 & Rural & $>15$ & $\begin{array}{l}\text { sBP }>140 \text { and } \\
d B P \geq 90\end{array}$ & 1005 & $\begin{array}{l}\text { sHTN 10.5; } \\
\text { dHTN 9.0 }\end{array}$ & $\begin{array}{l}\text { Cross } \\
\text { sectional }\end{array}$ \\
\hline Sayeed et al. ${ }^{21}$ & 2002 & $\begin{array}{l}\text { Urban and } \\
\text { rural }\end{array}$ & $\geq 20$ & $\begin{array}{l}\mathrm{sBP} \geq 140 \text { and } \\
\mathrm{dBP} \geq 90\end{array}$ & 2361 & $\begin{array}{l}\text { sHTN 14.4; } \\
\text { dHTN 9.1 }\end{array}$ & $\begin{array}{l}\text { Cross } \\
\text { sectional }\end{array}$ \\
\hline $\begin{array}{l}\text { Sayeed } \\
\text { et al. }{ }^{22}\end{array}$ & 2003 & Rural & $\geq 20$ & Not mentioned & 4923 & $\begin{array}{l}\text { Male } 15.7 ; \\
\text { female } 22.5\end{array}$ & $\begin{array}{l}\text { Cross } \\
\text { sectional }\end{array}$ \\
\hline $\begin{array}{l}\text { Zaman } \\
\text { et al. }{ }^{23}\end{array}$ & 2004 & Rural & $\geq 20$ & $\begin{array}{l}s B P \geq 140 \\
\pm d B P \geq 90 \pm \\
\text { medication }\end{array}$ & 1271 & 17.8 & $\begin{array}{l}\text { Cross } \\
\text { sectional }\end{array}$ \\
\hline $\begin{array}{l}\text { Chen et } \text { al. }^{24} \\
\text { HEALS study }\end{array}$ & 2006 & Rural & $\geq 18$ & $\begin{array}{l}\mathrm{sBP} \geq 140 \text { or } \\
\mathrm{dBP} \geq 90 \text { or, } \\
\text { medication }\end{array}$ & 11116 & 13.3 & $\begin{array}{l}\text { Cross } \\
\text { sectional }\end{array}$ \\
\hline $\begin{array}{l}\text { Rahim et } \\
\text { al. }^{25}\end{array}$ & 2007 & Rural & $\geq 20$ & $\begin{array}{l}S B P \geq 140 \text { and } \\
d B P \geq 90\end{array}$ & $\begin{array}{l}\text { 1999: } \\
4757 ; \\
2004: \\
3981\end{array}$ & $\begin{array}{lll}\text { 1999: } & \text { sHTN } & 6.8 \text {, } \\
\text { dHTN } & 6.6 ; & 2004: \\
\text { sHTN } & 8.5, & \text { dHTN } \\
6.9 & & \end{array}$ & $\begin{array}{l}\text { Cross } \\
\text { sectional }\end{array}$ \\
\hline $\begin{array}{l}\text { Van Minh } \\
\text { et al. }{ }^{12}\end{array}$ & 2008 & Rural & $25-64$ & Self-reported & 7153 & $\begin{array}{l}\text { HSID: } 14.6 ; \\
\text { WATCH: } 17.1 \\
\text { Matlab: } 10.6\end{array}$ & $\begin{array}{l}\text { Cross } \\
\text { sectional }\end{array}$ \\
\hline $\begin{array}{l}\text { Bangladesh NCD } \\
\text { Risk Factor } \\
\text { Survey } 2010^{27}\end{array}$ & 2010 & $\begin{array}{l}\text { Urban and } \\
\text { rural }\end{array}$ & $\geq 25$ & $\begin{array}{l}\mathrm{BP} \geq 140 / 90 \text { or, } \\
\text { medication }\end{array}$ & 9,275 & 17.9 & $\begin{array}{l}\text { Cross } \\
\text { sectional }\end{array}$ \\
\hline Parr et al. ${ }^{16}$ & 2011 & $\begin{array}{l}\text { Urban and } \\
\text { rural }\end{array}$ & $>25$ & Self-reported & 8591 & 13.60 & \\
\hline Cravedi et al. ${ }^{28}$ & 2012 & Rural & $>18$ & By clinical staff & 1518 & 18.5 & $\begin{array}{l}\text { Cross } \\
\text { sectional }\end{array}$ \\
\hline BDHS $2011^{29}$ & 2013 & $\begin{array}{l}\text { Urban and } \\
\text { rural }\end{array}$ & $\geq 35$ & $\begin{array}{l}\text { Pre-HTN: } \\
\text { sBP } 120-139 \pm \\
\text { dBP } 80-89 ; \\
\text { HTN: sBP } \geq 140 \\
+ \text { dBP } \geq 90 \text { or, } \\
\text { medication }\end{array}$ & 17,964 & $\begin{array}{l}\text { In male: } \\
\text { Pre-HTN 27, HTN } \\
\text { 19; } \\
\text { In females: Pre- } \\
\text { HTN 28, HTN } 32\end{array}$ & $\begin{array}{l}\text { Cross } \\
\text { sectional }\end{array}$ \\
\hline Bhowmik et al. ${ }^{30}$ & 2013 & Rural & $\geq 20$ & $\begin{array}{l}s B P \geq 140 \text { and } \\
d B P \geq 90\end{array}$ & 4757 & $\begin{array}{l}\text { 1999: } 14.3 ; \\
\text { 2004: } 18.4 ; 2009: \\
14.0\end{array}$ & $\begin{array}{l}\text { Cross } \\
\text { sectional }\end{array}$ \\
\hline Neupane et al. ${ }^{31}$ & 2014 & $\begin{array}{l}\text { Urban and } \\
\text { rural }\end{array}$ & & $\begin{array}{l}\text { Pre-HTN: } \\
\text { sBP } 120-139 \pm \\
\text { dBP } 80-89 ; \\
\text { HTN: } \\
\text { sBP } \geq 140 \pm \text { dBP } \\
\geq 90 \text { or, medication }\end{array}$ & & 17.9 & $\begin{array}{l}\text { Meta- } \\
\text { analysis }\end{array}$ \\
\hline Khanam et al. ${ }^{32}$ & 2015 & Rural & $\geq 25$ & $\begin{array}{l}\text { Pre-HTN: } \\
\text { sBP } 120-139 \pm \\
\text { dBP } 80-89 ; \\
\text { HTN: } \\
\text { sBP } \geq 140 \pm \text { dBP } \\
\geq 90 \text { or, medication }\end{array}$ & 6,094 & $\begin{array}{l}\text { Pre-HTN 31.9; } \\
\text { HTN } 16.0\end{array}$ & $\begin{array}{l}\text { Cross } \\
\text { sectional }\end{array}$ \\
\hline Islam et al. ${ }^{33}$ & 2016 & Rural & $\geq 30$ & $\begin{array}{l}\mathrm{sBP} \geq 140 \text { and } \\
\mathrm{dBP} \geq 90 \text { or, } \\
\text { self-reported }\end{array}$ & 3096 & 40 & $\begin{array}{l}\text { Cross } \\
\text { sectional }\end{array}$ \\
\hline Fatema et al. ${ }^{34}$ & 2016 & $\begin{array}{l}\text { Urban and } \\
\text { rural }\end{array}$ & Different & Different & & 15.1 & $\begin{array}{l}\text { Meta- } \\
\text { analysis }\end{array}$ \\
\hline
\end{tabular}

$\mathrm{BP}$, blood pressure; sBP, systolic blood pressure; dBP, diastolic blood pressure; HTN, hypertension; sHTN, systolic hypertension; dHTN, diastolic hypertension; BDHS, Bangladesh Demographic and Health Survey; NCD, non-communicable diseases; HEALS, Health Effects of Arsenic Longitudinal Study; HSID, Health System and Infectious Disease; WATCH, Woman Abuse Tracking in Clinics and Hospitals 
Rheumatic fever (RF) and rheumatic he art disease (RHD) are common CVD in Bangladesh. Data regarding the incidence and prevalence of these conditions vary widely. ${ }^{36-42}$ (Table 3 ). However, over the past 3 decades, there is a declining trend of acute RF in the country. However, chronic RHD continues to be an important public health problem here. Current prevalence of RF and RHD may be $<1 / 1000.43$ Recently, conventional and portable echocardiography is being used increasingly in studies concerning RF and RHD, as a result, more and more subclinical cases of RHD are being diagnosed. So, the prevalence of RF and RHD estimated so far may not be accurate, and the true prevalence of RHD may be much higher in Bangladesh as well.

Data regarding the incidence and prevalence of heart failure at the community level in Bangladesh are almost non-existing. In a hospital-based retrospective study at a tertiary cardiac hospital in Dhaka City ${ }^{44}$, about oneseventh (1970 out of 14009) of the patients admitted between January 2005 and August 2006 had heart failure.
Majority (35.79\%) had CAD as the principal etiological factor, whereas hypertension was the primary risk factor for HF in $29.14 \%$ of cases. In another hospital-based study conducted in the National Institute of Cardiovascular Diseases (NICVD), Dhaka in 2009 involving 780 patients, $27.25 \%$ had heart failure. ${ }^{45}$

Little is known regarding the incidence and prevalence of congenital heart disease (CHD) in Bangladesh. A proportion of $\mathrm{CHD}$ in children may remain undetected unless specific efforts are made to diagnose them. In a prospective, hospital based study conducted over January 2006 to December 2008 in the Pediatric Cardiology unit of Combined Military Hospital (CMH) Dhaka, 142 babies out of 5668 live birth had CHD, giving an incidence of 25/1000 live births. Most common CHDs were atrial septal defect (ASD, 26\%), ventricular septal defect (VSD, 16.9\%), patent ductus arteriosus (PDA, $18 \%$ ), tetralogy of Fallot (TOF, 14\%), and pulmonary stenosis (PS, 7.75\%). ${ }^{46}$ Another study ${ }^{47}$ conducted in Dhaka Shishu Hospital from January 2008 to December

Table-III

Prevalence of RF and RHD in Bangladesh.

\begin{tabular}{|c|c|c|c|c|c|c|c|}
\hline Reference & Year & Place & $\begin{array}{l}\text { Age, } \\
\text { years }\end{array}$ & $\begin{array}{c}\text { Echo used } \\
\text { or not }\end{array}$ & No. screened & $\begin{array}{l}\text { Prevalence } \\
\text { (per 1000) }\end{array}$ & Type of study \\
\hline Malik $^{10}$ & 1976 & Urban and rural & $\begin{array}{l}\text { Different } \\
\text { ages }\end{array}$ & No & 7062 & $\begin{array}{l}\text { 7.5, combined RF and } \\
\text { RHD }\end{array}$ & $\begin{array}{l}\text { Community } \\
\text { project }\end{array}$ \\
\hline $\begin{array}{l}\text { Ahmed et } \\
\text { al. }^{36}\end{array}$ & 1991 & Rural & $5-15$ & $\begin{array}{l}\text { Yes, in selected } \\
\text { cases }\end{array}$ & 5923 & $\begin{array}{l}\text { RF 1.2; } \\
\text { RHD 1.3 }\end{array}$ & $\begin{array}{l}\text { Community } \\
\text { project }\end{array}$ \\
\hline $\begin{array}{l}\text { Haque et } \\
\text { al. }^{37}\end{array}$ & 1992 & Urban and rural & $5-15$ & $\begin{array}{l}\text { Yes, in selected } \\
\text { cases }\end{array}$ & $\begin{array}{l}\text { Urban } 9875, \\
\text { rural } 5923\end{array}$ & $\begin{array}{l}\text { 3.6, combined RF and } \\
\text { RHD }\end{array}$ & $\begin{array}{l}\text { School and } \\
\text { house to house } \\
\text { survey }\end{array}$ \\
\hline $\begin{array}{ll}\text { Banoo et } \\
\text { al. }^{38}\end{array}$ & $1984-85$ & Urban & $4-17$ & No & 4349 & $\begin{array}{l}\text { RF 43.9; } \\
\text { RHD 5.05 }\end{array}$ & School survey \\
\hline $\begin{array}{l}\text { Mahmud et } \\
\text { al. }^{39}\end{array}$ & 1989 & Urban & $5-18$ & $\begin{array}{l}\text { Yes, in selected } \\
\text { cases }\end{array}$ & 5011 & $\begin{array}{l}\text { RF 0.85; } \\
\text { RHD } 2.8\end{array}$ & School survey \\
\hline $\begin{array}{l}\text { Begum et } \\
\text { al. }^{40}\end{array}$ & 1990-91 & Urban & 5-18 & $\begin{array}{l}\text { Yes, in selected } \\
\text { cases }\end{array}$ & 10538 & $\begin{array}{l}\text { RF 2.37; } \\
\text { RHD } 0.189\end{array}$ & School survey \\
\hline $\begin{array}{l}\text { Majumder } \\
\text { et al. }^{41}\end{array}$ & 2004 & Rural & $5-16$ & No & 947 & $\begin{array}{l}\text { RF 4.22; } \\
\text { RHD } 0\end{array}$ & School survey \\
\hline $\begin{array}{l}\text { Zaman et } \\
\text { al. }^{42}\end{array}$ & 2005 & Urban and rural & 5-19 & Yes & 56827 & $\begin{array}{l}\text { RF 0.6; } \\
\text { RHD } 0.3\end{array}$ & $\begin{array}{l}\text { Cross-sectional } \\
\text { survey }\end{array}$ \\
\hline
\end{tabular}

$\mathrm{RF}$, rheumatic fever; RHD, rheumatic heart disease 
2009 prospectively and from January 1998to December 1999 retrospectively, involved subjects aging from $1^{\text {st }}$ day of life to 12 years of age. Majority were acyanotic congenital heart disease $(75 \%$ and $78.5 \%$ in the past and present respectively); VSD was the commonest lesion ( $32.7 \%$ and $26.9 \%$ respectively), followed by ASD (25.6\% and $21.2 \%$ respectively). TOF was the commonest cyanotic lesion both in the past and present.VSD $(42.6 \%)$ was the commonest type of congenital heart disease reported in another prospective 1-year study among the admitted children (newborn to 12 years) in the Department of Paediatrics of Rajshahi Medical College \& Hospital. ${ }^{48}$ Other major types were TOF (18.3\%), ASD (14.8\%), and PDA (7.8\%). A more recent retrospective study from 2010 to 2013 conducted in Sir Salimullah Medical College Hospital, Dhaka, demonstrated that out of 6520 cases of live births, 196 had CHD giving the incidence 30/1000 live births. Among the congenital heart lesions, the prevalence of ASD, VSD, PDA, TOF and transposition of great arteries (TGA) were $20.41 \%, 13.78 \%, 10.71 \%, 8.67 \%$ and $4.59 \%$ respectively. ${ }^{49}$

At present, there are probably no available data regarding arrhythmias, cardiomyopathies and peripheral arterial disease in Bangladesh.

Data regarding prevalence of stroke in Bangladesh is inadequate. The prevalence of stroke has been estimated from a community study involving 15,627 participants aged $>40$ years ${ }^{50}$ with an overall prevalence of stroke of $0.30 \%$. Stroke prevalences were reported as $0.20 \%, 0.30 \%, 0.20 \%, 1.00 \%$, and $1.00 \%$ for the age groups of 40-49 years, 50-59 years, 60-69 years, 7079 years, and 80 years and above, respectively. In a recently published study, the prevalence of stroke in rural population aged $>30$ years has been found to be $0.94 \%$ in general, $1.45 \%$ in male and $0.45 \%$ in female. ${ }^{51}$
Data regarding the prevalence of CVDs in Bangladesh are insufficient and not homogeneous. Well-designed epidemiological studies are needed to generate reliable and uptodate data which can be applied in formulation and implementation of healthcare policies at national level. , Realizing these limitations the estimated current prevalence of different CVDs in the country is shown in Table 4.

\section{Risk factors of CVD in Bangladesh Ethnicity and genetics}

Ethnicity is an important determinant of prevalence of CVD specially CAD. When compared to other ethnicities, South Asians i.e. individuals originally from India, Pakistan, Nepal, Bangladesh and Sri Lanka, have a high prevalence of CAD and associated risk factors. ${ }^{52-4}$ South Asians have a 3 to 5 -fold increased risk of myocardial infarction. ${ }^{55}$ South Asians also present with more severe disease and at an earlier age than Caucasians. ${ }^{56}$ The London Life Sciences Population Study (LOLIPOP) and the Pakistan Risk of Myocardial Infarction Study (PROMIS) have given important insights into the genetics associated with the undue susceptibility of the South Asians to cardiometabolic conditions including CAD. ${ }^{57,58}$ Over 25 cosmopolitan loci for $\mathrm{CAD}^{59,60}$ and type 2 diabetes $^{61-3}$ have already been discovered showing that there are genetic risk factors for cardio-metabolic conditions that apply to people of South Asian ancestry and to people of European ancestry. Bangladeshis appear to share with other South Asian populations the same susceptibility to CAD; however, the probability of existence of an even more prone 'Bangladeshi ethnicity' in not impossible. ${ }^{17}$ In concert with this concept, the initial analyses of the ongoing Bangladesh Risk of Acute Vascular Events (BRAVE) study indicates that Bangladeshis are genetically distinct from major non-South Asian

Table-IV

Prevalence of cardiovascular diseases in Bangladesh.

\begin{tabular}{|l|l|}
\multicolumn{1}{|c|}{ Disease } & \multicolumn{1}{c|}{ Prevalence } \\
\hline Hypertension & $20-25 \%$ in adults \\
\hline Coronary artery disease & $4-6 \%$ in adults \\
\hline Rheumatic fever/Rheumatic heart disease & $<1 / 1000$ in children and young adults \\
\hline Congenital heart disease & $25-30 / 1000$ live births \\
\hline Stroke & $0.3-1.0 \%$ in adults \\
\hline $\begin{array}{l}\text { Heart failure, arrhythmias, cardiomyopathies and peripheral } \\
\text { arterial disease }\end{array}$ & No available data \\
\hline
\end{tabular}


ethnicities, as well as distinct from other South Asian ethnicities and were perhaps genetically closest to (though still distinct from) Sri Lankan Tamils. ${ }^{64}$ There may also be genetic susceptibility to hypertension. The association between angiotensin converting enzyme (ACE) gene polymorphism and blood pressure has been studied inadequately in Bangladeshi population. ${ }^{65,66}$ In 2002, Morshed et al. found positive association between ACE insertion/ deletion (I/D) polymorphism and hypertension in Bangladeshi population. Among the three $A C E ~ I / D$ variants, the DD genotype was associated with the highest value of both mean systolic and mean diastolic blood pressure $(p=<0.05)$ in men. In the overall population, blood pressure was highest in DD, intermediate in ID, and the least in II subjects. Further research is needed to clarify this relationship.

\section{Diabetes mellitus}

Diabetes has become a national health concern in Bangladesh. The BDHS 2011 showed the overall, agestandardized prevalence of diabetes and pre-diabetes to be $9.7 \%$ and $22.4 \%$, respectively; among urban residents, the age-adjusted prevalence of diabetes was $15.2 \%$ compared with $8.3 \%$ in rural residents. ${ }^{67,68}$ The prevalence of diabetes mellitus was $7.4 \%(95 \% \mathrm{Cl} 7.2-$ $7.7 \%$ ) in a recently published review involving 51,252 participants, and also there was an increasing trend of diabetes prevalence among urban and rural population in Bangladesh. ${ }^{69}$

According to the International Diabetes Federation assumption in 2010, the explosion in diabetes prevalence will place Bangladesh among the top 7 countries in terms of the number of people living with diabetes in $2030 .{ }^{70}$

\section{Smoking and smokeless tobacco use}

Tobacco use is quite common in Bangladesh. Bangladesh is one of the top 10 countries that make up two-thirds of the world population of smokers. ${ }^{71}$ According to the Bangladesh NCD risk factor survey 2010, the prevalence is $51.0 \%$ for any form of tobacco, $26.2 \%$ for smoking and $31.7 \%$ for smokeless tobacco (SLT). ${ }^{27}$ Current tobacco use is $43.3 \%$ in Bangladesh; exclusively smoking is $16.1 \%$, exclusively using SLT $20.3 \%$, and dual use of smoking and SLT is $6.8 \%$ according to the Global Adult Tobacco Survey (GATS).$^{72}$ The prevalence of smoking among men in Bangladesh is higher than the world average of daily smoking among men (37\% vs. $31.1 \%) .{ }^{73}$ According to a proportional mortality study, smoking causes about $25 \%$ of all deaths in Bangladeshi men aged between 25 to 69 years and an average loss of 7 years of life per smoker. ${ }^{74}$ However, currently published research does not provide conclusive evidence regarding the association between SLT use and CAD. In a recently published systematic review, 9 studies found no statistically significant positive association between SLT use and CAD, while 9 studies did find a positive association. ${ }^{75}$

\section{Dyslipidaemia}

The excess burden of CAD among South Asians appears to be primarily due to dyslipidemia that is characterized by high levels of apolipoprotein (apo) B, triglycerides (TG), and lipoprotein $(L p)(a)$; borderline high levels of lowdensity lipoprotein cholesterol (LDL-C); and low levels of high-density lipoprotein cholesterol (HDL-C) and apoA1. ${ }^{76}$ Liberal use of saturated fats and trans fats, deep frying, reuse of cooking oil, and overcooking leading to destruction of folates may all contribute to dyslipidaemia in this population. ${ }^{78}$ Studies exclusively related to dyslipidaemia are sparse in Bangladesh. A study ${ }^{79}$ involving 51,353 predominantly urban population during 2005-2011 demonstrated significantly higher mean serum levels of total cholesterol (TC), LDL-C, TG, LDL to HDL cholesterol ratio and TC to HDL-C ratio among younger adults aged 30-39 years compared to other age groups, regardless of sex, which may lead to microvascular complications. Another study 80 involving 3201 individuals found rising trend of dyslipidaemia in sub-urban population; prevalence of dyslipidaemia was $16.6 \%$ in general and $22.2 \%$ in males and $15.9 \%$ in females. TC was high ( $>240 \mathrm{mg} / \mathrm{dl})$ in $16.9 \%$, LDL-C was high $(>160 \mathrm{mg} / \mathrm{dl})$ in $15.7 \%$, HDL-C was low $(<40$ $\mathrm{mg} / \mathrm{dl})$ in $8.8 \%$, and TG was high $(>200 \mathrm{mg} / \mathrm{dl})$ in $17.8 \%$ and very high $(>350 \mathrm{mg} / \mathrm{dl})$ in $2.0 \%$ population. Women had significantly higher TC and LDL-C in comparison to men above 40 years. Contrary to the popular belief, dyslipidaemia is common in rural people as well. ${ }^{81}$ Studies are needed to determine the lipoprotein profile of the population for better understanding of the contribution of dyslipidaemia to the aetiopathogenesis of CVD.

\section{Lifestyle related factors}

As a result of socioeconomic transition, lifestyle, as well as, the dietary pattern is changing in Bangladesh. Increasing prevalence of obesity, tobacco use, high intake of processed foods and less physical activity accompany this transition.

Prevalence of overweight and obesity is increasing. In general, $21.5 \%$ adults (male $21 \%$, female $22 \%$ ) have 
body-mass index (BMI) $\geq 25 \mathrm{~kg} / \mathrm{m}^{2}$; increased waist circumference is alarming especially in women $(33.7 \%) .{ }^{27}$ In a population-based, cross-sectional survey conducted in 2009 involving 2293 subjects aged $\geq 20$ years from rural Bangladesh ${ }^{82}$, the age standardized prevalence of overweight (BMI 23-24.9 kg/m $)$ and obesity (BMI $\geq 25 \mathrm{~kg} / \mathrm{m}^{2}$ ) were $17.7 \%$ (95\% confidence interval (Cl): $16.1,-19.2 \%)$ and $26.2 \%$ (95\% Cl: $24.4-27.9 \%)$, respectively. The age standardized prevalence of central obesity based on waist circumference (male $\geq 90$ \& female $\geq 80 \mathrm{~cm}$ ) and waist hip ratio (male $\geq 0.90$ and female $\geq 0.80$ ) were $39.8 \%(95 \% \mathrm{Cl}: 37.9,41.7 \%)$ and $71.6 \%$ (95\% Cl: $69.8,73.4 \%$ ) respectively. The prevalence of central obesity was more in female than male. Both total obesity and abdominal adiposity were associated with development of CAD in Bangladeshi population. ${ }^{83}$ Childhood obesity is a growing concern in this population as well. A recent review showed an increasing trend in childhood obesity over time in Bangladesh; prevalence ranged from less than $1 \%$ to $17.9 \%$ based on different reference standards, with higher percentage amongst urban children. ${ }^{84}$ In a recent countrywide cross sectional study, from June to September 2009 among 10,135 students of 6 to 15-year age group from both the urban and rural schools ${ }^{85}, 3.5 \%$ were obese, $9.5 \%$ were overweight and $17.6 \%$ were underweight. The proportion of obese and overweight students were greater among the students from urban schools $(5.6 \%$ and $10.6 \%$ respectively) compared to the students from rural schools $(1.2 \%$ and $8.6 \%$ respectively) (Risk difference, $\mathrm{RD}=4.3,95 \% \mathrm{Cl}=3.6,5.0 ; \mathrm{RD}=2.0,95 \% \mathrm{Cl}=0.1,3.1$ ). A recent study 86 found a high prevalence of overall and central obesity in adolescent girls in Bangladeshi population; the prevalence of obesity and overweight were $23 \%$ and $14 \%$, whereas the prevalence of central obesity was $26 \%$. Around $14 \%$ of girls in the normal weight group were centrally obese.

The prevalence of metabolic syndrome is also high in Bangladesh. In a recent population-based crosssectional study involving 2,293 randomly selected participants (aged $\geq 20$ years) in a rural community in Bangladesh, the age-adjusted prevalence of metabolic syndrome was $30.7 \%$ (males $30.5 \%$; females $30.5 \%$ ) using the National Cholesterol Education Programme (NCEP) Adult Treatment Panel III (ATP III) definition, and $24.5 \%$ (males $19.2 \%$, females $27.5 \%$ ) using the International Diabetes Federation (IDF) definition. ${ }^{87}$ In another study, the prevalence of metabolic syndrome was found to be $20.7 \%, 11.2 \%$ and $8.6 \%$ following ATP III, IDF and by the World Health Organization (WHO) definitions, respectively. ${ }^{88}$ Metabolic syndrome is probably commoner in women. ${ }^{88,89}$ The prevalence of metabolic syndrome was found to be $31.25 \%$ (NCEP ATP III modified) in 1485 rural women of Bangladesh aged $\geq 15$ years. ${ }^{90}$

Sedentary life style may have an association with CAD. Bangladesh NCD Risk Factor Survey $2010^{27}$ found low level of physical activity ( $<600$ metabolic equivalentminutes) per week. Future research is needed to determine the association of physical inactivity to the high incidence of CAD in Bangladesh.

Dietary pattern may play role in aetiopathogenesis of CVD. Like many other developing countries, socioeconomic transition is accompanied by a changing dietary pattern in Bangladesh. A prospective cohort analyses in 11,116 participants enrolled in the Health Effects of Arsenic Study in Araihazar, Bangladesh, with a follow-up of average 6.6 years, an animal protein-rich diet in rural Bangladesh was associated with increased risk of CVD mortality, especially among smokers. ${ }^{91}$ Diets were classified in patterns: (i) a "balanced" pattern, comprised of steamed rice, red meat, fish, fruit and vegetables; (ii) an "animal protein" diet, which was more heavily weighted towards eggs, milk, red meat, poultry, bread, and vegetables; and (iii) a "gourd and root vegetable" diet that heavily relied on a variety of gourds, radishes, pumpkin, sweet potato, and spinach. 'Western' dietary pattern was associated with greater longitudinal increase in blood pressure in comparison to the 'gourd vegetable' dietary pattern and the 'balanced' dietary pattern. ${ }^{92}$ Similar observations were found in a previous study. ${ }^{93}$ In the participants (n-1149) randomly selected from the Health Effects of Arsenic Longitudinal Study, a gourd/root vegetable diet in this Bangladeshi population positively correlated with carotid intima-media thickness a validated surrogate marker of preclinical atherosclerosis, while a balanced diet was associated with decreased intima-media thickness. ${ }^{94}$

The average Bangladeshi eats a total of $126 \mathrm{~g}$ of fruit and vegetables daily ${ }^{95}$, which is far below the minimum daily consumption of $400 \mathrm{~g}$ of vegetables and fruit recommended by Food and Agriculture Organization of the United Nations and the WHO. ${ }^{96}$ Bangladesh NCD Risk Factor Survey 2010 revealed $95.7 \%$ people consume inadequate fruit and/or vegetables $(<5$ servings per day $)^{26}$

High salt intake appears to be a significant problem with Bangladeshi population based on the data from salt production and sales, average daily intake has been calculated to be $15 \mathrm{~g} \cdot{ }^{97} \mathrm{~A}$ more recent study using spot urine analysis found very high average sodium intake of 
$21 \mathrm{~g} /$ day. ${ }^{98}$ Considering these data, salt intake in this country appears to be much higher than what is recommended by the WHO (sodium chloride $<5 \mathrm{~g} /$ day, sodium <2 g/day) ${ }^{99}$ or the 2015-2020 Dietary Guidelines for Americans (sodium $<2.3 \mathrm{~g} /$ day in general and children ages $>14$ years, and $<1.5 \mathrm{~g} /$ day for individuals with prehypertension and hypertension). ${ }^{100}$ Extra salt intake along with age, BMI, physical inactivity, tobacco use and family history of stroke/CVD was found to have significant relationship with hypertension and pre-hypertension in a cross-sectional survey involving participants aged e" 25 years in an urban area in Dhaka between June to December 2012. ${ }^{101}$ Also, more than 35 million people in coastal Bangladesh are vulnerable to increasing freshwater salinization; elevated salinity in drinking water has been found to be associated with higher BP in young coastal populations. ${ }^{102}$ The overall risk perception regarding excessive salt consumption is low and there is widespread belief that the cooking process can render the salt harmless. ${ }^{103} \mathrm{High}$ salt intake presumably contributes to hypertension, which is an established risk factor for CAD.

\section{Low-Birth Weight and Childhood Malnutrition}

The developmental origin theory of CAD proposes that undernutrition in utero permanently changes body functions and metabolism leading to an increased risk of CAD in adult life. ${ }^{104-6}$ However, a recently published study involving German youths aged 3-18 years did not find significant association between birth weight and traditional cardiovascular risk factors. ${ }^{107}$ Low birth weight $(<2,500 \mathrm{~g})$ affects $36 \%$ of infants in Bangladesh, more than twice of $15 \%$ threshold that indicates a public health burden. Also, $<1 \%$ of infants are born with very low birth weight $(<1,500 \mathrm{~g}) .{ }^{108}$ Research is needed to explore association, if any, between the two public health problems i.e. low birth weight and CAD in this community. Under-nutrition during childhood, adolescence, or young adulthood is related to CAD and stroke in adult life. ${ }^{109,110}$ Despite the progress achieved, rates of malnutrition in Bangladesh are among the highest in the world; more than $54 \%$ of preschool-age children, equivalent to more than 9.5 million children, are stunted, 56\% are underweight and more than $17 \%$ are wasted. ${ }^{111}$ An analysis revealed that among the children under five years of age $16 \%$ were severely stunted, $25 \%$ moderately stunted, $3 \%$ severely wasted and $14 \%$ were moderately wasted; furthermore, $11 \%$ of the children were severely underweight and $28 \%$ were moderately underweight. ${ }^{112}$ Such a high prevalence of low-birth weight childhood under-nutrition may facilitate development of CAD in adult in Bangladeshi population.

\section{Hypovitaminosis D}

Role of Vitamin D in cardiovascular health is of much interest at present. Experimental, as well as, some observational studies suggest that vitamin $D$ and its metabolites are integrally related to blood pressure and the renin-angiotensin system. Vitamin D insufficiency affects almost $50 \%$ of the population worldwide. Few studies have been carried out to determine the prevalence of hypovitaminosis D in Bangladesh. In a recently published study involving husbands of pregnant women in Dhaka, vitamin D deficiency was prevalent in both men and women but men had substantially higher circulating 25-hydroxycholecalciferol (25(OH)D) concentrations and lower risk of vitamin $D$ deficiency than their pregnant spouses; gender-related lifestyle factors, rather than ethnic or environmental factors likely explain the high risk of vitamin $\mathrm{D}$ deficiency among women of reproductive age in Bangladesh. ${ }^{113}$ Vitamin $D$ deficiency was found prevalent in young infants in rural Bangladesh. ${ }^{114}$ High prevalence of suboptimal serum 25(OH)D level $(<25$ $\mathrm{nmol} / \mathrm{l}$ ) was described in lactating women of low socioeconomic status and those wearing Shari, a traditional ladies wear. ${ }^{115}$ In another survey of women aged 18-60 years, serum 25(OH)D levels were $<40 \mathrm{nmol} /$ I in $78 \%$ of 36 university students and $83 \%$ of 30 veiled women. ${ }^{116}$ Further research is needed to evaluate the association, if any, between vitamin $\mathrm{D}$ deficiency and CAD in Bangladesh.

\section{Chronic arsenicosis}

Arsenic contamination of groundwater in Bangladesh has been recognized as a massive public health hazard. Positive association has been found between chronic arsenic exposure and CVD ${ }^{117-21}$, ECG abnormalities $^{121}$, hypertension ${ }^{122}$, and stroke ${ }^{123}$. Chronic arsenic exposure may facilitate systemic inflammation and vascular endothelial dysfunction, which may, in turn, increase the risk of CVD. The Health Effects of Arsenic Longitudinal Study in Bangladesh (2007-2008) has reported positive association between arsenic exposure from drinking water and plasma levels of markers of systemic inflammation and endothelial dysfunction. ${ }^{124}$ In the same population, positive association has been found between inorganic arsenic exposure from drinking water and risk of hypertension ${ }^{125-6}$, and more recently, increased cardiovascular mortality. Further basic, as 
well as, clinical research is needed to better define the role of arsenicosis in the aetiopathgenesis of CVD in Bangladeshi population.

\section{Air Pollution}

In the recent years, air pollution has been suggested to contribute to cardiovascular illness. The overall evidence is consistent with a causal relationship between exposure to particulate matter $<2.5 \mu \mathrm{m}$ in diameter $\left(\mathrm{PM}_{2.5}\right)$ and cardiovascular morbidity and mortality. ${ }^{128}$ Air pollution is a significant problem specially in the urban areas of Bangladesh with marked temporal and directional variations in particulate matter concentrations. ${ }^{129}$ A study to evaluate the emissions and air quality in megacities found Dhaka to have the poorest air quality in respect of total suspended particles (TSP), sulfur dioxide $\left(\mathrm{SO}_{2}\right)$, and nitrogen dioxide $\left(\mathrm{NO}_{2}\right)$ among the megacities, and the pollutant levels were far beyond the WHO standard. ${ }^{130}$ One recent study involving Dhaka City found elevated concentrations of the number, surface and mass distributions of particulate matters; fine particles (0.5$1.0 \mu \mathrm{m}$ ) derived from vehicle emissions were dominating the aerosol particles number concentrations. ${ }^{131}$ Investigation of sources of atmospheric aerosol at urban and semi-urban areas in Bangladesh revealed soil dust, road dust, cement, sea salt, motor vehicles and biomass burning to be the main sources of air pollution. ${ }^{132-1}$ Vehicular emissions and emission from brick kiln are the major contributors to air pollution in Dhaka especially during dry seasons, while contribution from emissions from metal smelters increases during rainy seasons. ${ }^{134}$ In rural areas, indoor air pollution from the combustion of traditional biomass fuels is a significant public health problem in many developing countries, including Bangladesh. One study found the major constituent of the particulate matter in rural air was carbonaceous matter. ${ }^{135}$ Chronic exposure to the particulate matter in indoor air from combustion of traditional biomass fuels may be a contributor to the CAD in rural women who are specially concerned with cooking. In a retrospective cohort study in Matlab, Bangladesh, household solidfuel use was associated with increased respiratory mortality and non-significantly increased risk of cardiovascular mortality. ${ }^{136}$ Further research is needed to elucidate the role of air pollution to the aetiopathogenesis of CVD in Bangladeshi population.

\section{Cardiovascular Care in the Past}

Traditionally, cardiac diseases were treated by physicians specialized in medicine. In the Government sector, the cardiac patients were managed in the medicine outpatient and inpatient departments; the facilities were limited to the medical college hospitals, the formerly Institute of Postgraduate Medicine \& Research (IPGMR), and the Combined Military Hospital $(\mathrm{CMH})$. The first coronary care unit was established at IPGMR where electrocardiogram (ECG) and phono-cardiographs were available.

First integrated cardiovascular care started in this country with the establishment of the then Institute of Cardiovascular Diseases (ICVD), later named as the National Institute of Cardiovascular Diseases (NICVD) in 1978, and formally in $3^{\text {rd }}$ April 1981. Generous technical and financial cooperation was provided by the Government of Japan in the advent of cardiovascular care in Bangladesh. Besides medical management, invasive diagnostic and therapeutic modalities were started there. First permanent pacemaker implantation was done in 1981. Since the introduction of angioplasty by Gruentzig in 1977, Bangladesh took more than a decade to make appropriate utilization of this technology. Percutaneous transluminal coronary angioplasty (PTCA) was introduced in ICVD by foreign experts in 1987; the first case was failed, while 1 case was successfully done in 1990. First PTCA was done by Bangladeshi team in 1995, first coronary stenting in 1997. ${ }^{137-9}$ First pulmonary valvuloplasty was done in 1987 , while percutaneous transluminal mitral commissurotomy (PTMC) was introduced in1996. For the first time, few cases of closed mitral commissurotomy (CMC) were done in IPGMR in 1973 by Prof. Ali Ashraf, and then in National Institute of Diseases of Chest \& Hospital (NIDCH) in 1979 by Prof. SR Khan. (Ahmed NU. Professor of Cardiac Surgery. Personal communication. 25 Dec 2013). First open heart surgery was done in NICVD in 1981, while coronary artery bypass grafting (CABG) was done in NICVD for the first time in 1985. CMC started in NICVD in 1980, and subsequently, a good number of cases were done at low cost with good results. ${ }^{140-1}$ Under the patronization of Dr. Rafique Ahmed of USA, non-pharmacological management of cardiac arrhythmia started in Bangladesh; an electrophysiology (EP) lab was established in NICVD, and the first EP study was done in July 2004. Also under his supervision, automated implantable cardioverter-defibrillator (AICD) was implanted for the first time in NICVD in 2005. First device closure of PDA was done in 2006 in the same institute.

\section{Present Status of Cardiovascular Care Facilities}

After the 80s, cardiovascular care facilities in Bangladesh have increased steadily. At present, a good number of institutions are rendering cardiovascular care throughout the country; also, they are becoming decentralized. The cardiac care institutions in Bangladesh are public, private and autonomous. Some are dedicated cardiac institutions, while others are in fact multi-specialty institutions having cardiac care facilities. At present, cardiovascular intervention and surgical facilities are available approximately in 30 and 25 institutions respectively. There are 39 catheterization laboratories as in November, 2016. Almost all conventional noninvasive modalities including ECG, echocardiography, 
exercise tolerance test are being more widely used for diagnosis of cardiac diseases. Side by side, invasive modalities are becoming more and more available; facilities for coronary angiogram and cardiac catheterization are rapidly expanding. More sophisticated diagnostic facilities including computed tomography (CT) coronary angiography, transesophageal and 3dimensional echocardiography, electrophysiological study, fractional flow reserve, and optical coherence tomography are available in selected centres.

Besides diagnostic modalities and techniques, treatment facilities have also increased in numbers. Besides percutaneous coronary intervention $(\mathrm{PCl})$, and PTMC, radiofrequency ablation for arrhythmias, AICD implantation, biventricular pacing, and device closure of shunt lesions are also available in practice. Different types of CABGs including OBCAB, minicab, midCAB, valve surgeries, surgery of congenital heart lesions, and importantly, vascular surgeries are in rapid evolution.
Classically, severe cases of mitral stenosis with suitable valve morphology were managed by surgery i.e. CMC. However, open mitral commissurotomy (OMC) is being used for suitable, complicated cases, like before. On the other hand, for mitral valve replacement, some bioprostheses were used initially, which were later replaced by metallo-prostheses. Initial ball-and-case metallic valves are out of use now-a-days, majority of the prostheses used today are bileaflet valves. In the recent years, primary angioplasty is being performed in Government ${ }^{14}$, as well as, in private ${ }^{144}$ centers.

At present, no complete registry concerning CVD and cardiovascular care including interventions exist in Bangladesh. Hence, the available data are incomplete. Recently, a registry has been formulated and maintained by the Bangladesh Association of Cardiovascular and Thoracic Anaesthesiologists (BACTA); the purpose is to maintain data regarding the cardiovascular and thoracic operations done throughout the country. A registry involving

Table-V

Catheterization laboratory procedures performed in the NICVD in 2001-2016. (Rahman SW. Statistics Officer, NICVD. Personal communication. 28 February 2017)

\begin{tabular}{|c|c|c|c|c|c|c|c|c|c|c|c|c|c|c|c|c|}
\hline Procedures & 2001 & 2002 & 2003 & 2004 & 2005 & 2006 & 2007 & 2008 & 2009 & 2010 & 2011 & 2012 & 2013 & 2014 & 2015 & 2016 \\
\hline $\begin{array}{l}\text { Coronary } \\
\text { angiography }\end{array}$ & 1043 & 1378 & 2827 & 3210 & 2780 & 3105 & 3266 & 3980 & 4437 & 4711 & 4426 & 4881 & 4239 & 4241 & 3452 & 5537 \\
\hline Cardiac Cath & 250 & 206 & 308 & 225 & 227 & 229 & 295 & 380 & 340 & 334 & 251 & 256 & 240 & 183 & 99 & 163 \\
\hline $\begin{array}{l}\text { Renal } \\
\text { angiography }\end{array}$ & 04 & 06 & 13 & 69 & 06 & 0 & 0 & 0 & 01 & 06 & 12 & 1 & 05 & - & - & - \\
\hline $\begin{array}{l}\text { Renal } \\
\text { angioplasty }\end{array}$ & 0 & 0 & 0 & 0 & 0 & 0 & 0 & 0 & 09 & 07 & 17 & 6 & 04 & - & - & - \\
\hline $\begin{array}{l}\text { Peripheral } \\
\text { angiography }\end{array}$ & 116 & 97 & 42 & 93 & 85 & 106 & 87 & 112 & 112 & 124 & 124 & 120 & 150 & 121 & 112 & 186 \\
\hline $\mathrm{PCI}$ & 163 & 228 & 371 & 599 & 488 & 584 & 574 & 889 & 1149 & 1312 & 1254 & 1681 & 1828 & 1898 & 1413 & 2316 \\
\hline $\begin{array}{l}\text { Peripheral } \\
\text { angioplasty }\end{array}$ & 0 & 0 & 0 & 0 & 04 & 7 & 43 & 23 & 03 & 18 & 12 & 22 & 13 & - & 2 & 40 \\
\hline PTMC & 74 & 92 & 189 & 273 & 295 & 280 & 20 & 130 & 154 & 187 & 117 & 137 & 137 & 111 & 89 & 111 \\
\hline Device closure & 0 & 0 & 0 & 0 & 0 & 01 & 0 & 0 & 0 & 0 & 0 & - & - & - & 69 & 165 \\
\hline EPS \& RFA & 0 & 0 & 0 & 0 & 0 & 161 & 204 & 113 & 177 & 66 & 72 & 56 & 57 & 35 & 130 & 255 \\
\hline PPM & 244 & 344 & 320 & 333 & 368 & 321 & 359 & 414 & 487 & 402 & 418 & 461 & 439 & 525 & 552 & 568 \\
\hline TPM & 525 & 634 & 646 & 715 & 708 & 675 & 850 & 741 & 950 & 647 & 905 & 1090 & 910 & 992 & 1077 & 1198 \\
\hline Others & 04 & 11 & 12 & 13 & 07 & 04 & 0 & 18 & 40 & 56 & 34 & 97 & 93 & 123 & 93 & 191 \\
\hline Total & 2423 & 2996 & 4728 & 5530 & 4968 & 5473 & 5698 & 6800 & 7859 & 7870 & 7642 & 8808 & 8115 & 8229 & 7088 & 10730 \\
\hline
\end{tabular}

NICVD, National Institute of Cardiovascular Diseases; PCI, Percutaneous coronary intervention; PTMC, Percutaneous transvenous mitral commissurotomy; EPS, Electrophysiological study; RFA, Radiofrequency ablation; PPM, Permanent pacemaking; TPM, Temporary pacemaking. 
Table-VI

Cardiovascular surgeries done in the NICVD in 2001-2016. (Rahman SW. Statistics Officer, NICVD. Personal communication. 28 February 2017)

\begin{tabular}{|c|c|c|c|c|c|c|c|c|c|}
\hline \multirow{2}{*}{ Year } & \multicolumn{6}{|c|}{ Open heart surgery } & Closed heart & \multicolumn{3}{|c|}{ Vascular surgery } \\
\cline { 2 - 6 } & CABG & Valve & Congenital & Other & Total & surgery & Routine & Emergency & Total \\
\hline 2001 & 60 & 134 & 133 & 03 & 330 & 157 & 100 & 193 & 293 \\
\hline 2002 & 112 & 89 & 210 & 04 & 415 & 151 & 114 & 232 & 346 \\
\hline 2003 & 170 & 142 & 162 & 22 & 496 & 140 & 69 & 153 & 222 \\
\hline 2004 & 180 & 159 & 205 & 17 & 561 & 95 & 92 & 208 & 300 \\
\hline 2005 & 267 & 102 & 237 & 20 & 626 & 93 & 90 & 206 & 296 \\
\hline 2006 & 226 & 113 & 255 & 28 & 622 & 70 & 95 & 405 & 500 \\
\hline 2007 & 188 & 165 & 256 & 46 & 655 & 58 & 121 & 447 & 568 \\
\hline 2008 & 233 & 182 & 327 & 21 & 763 & 63 & 152 & 840 & 992 \\
\hline 2009 & 218 & 264 & 364 & 11 & 854 & 71 & 219 & 1001 & 1220 \\
\hline 2010 & 152 & 304 & 365 & 37 & 859 & 88 & 254 & 1036 & 1290 \\
\hline 2011 & 101 & 207 & 342 & 67 & 717 & 98 & 183 & 1640 & 1823 \\
\hline 2012 & 175 & 249 & 468 & 57 & 949 & 82 & 254 & 1274 & 1528 \\
\hline 2013 & 147 & 293 & 450 & 26 & 916 & 41 & 265 & 1214 & 1479 \\
\hline 2014 & 103 & 310 & 492 & 28 & 943 & 48 & 265 & 1258 & 1523 \\
\hline 2015 & 147 & 239 & 393 & 149 & 928 & 31 & 301 & 1560 & 1861 \\
\hline 2016 & 206 & 226 & 464 & 99 & 995 & & 222 & 1602 & 1824 \\
\hline
\end{tabular}

NICVD, National Institute of Cardiovascular Diseases; CABG, Coronary artery bypass graft

Table-VII

Cardiac surgeries done in Bangladesh in 2015. ${ }^{145-6}$

\begin{tabular}{|c|c|c|c|}
\multicolumn{2}{|c|}{ Type of surgery } & $\mathbf{2 0 1 4}$ & \multicolumn{2}{c|}{53015} \\
\hline \multirow{3}{*}{ Coronary } & CABG & 4809 & 83 \\
\cline { 2 - 4 } & CABG+Valve/ASD/VSD & 77 & 509 \\
\hline \multirow{2}{*}{ Valvular } & MVR & 535 & 251 \\
\cline { 2 - 4 } & AVR & 248 & 151 \\
\cline { 2 - 4 } & DVR & 172 & 779 \\
\hline \multirow{2}{*}{ Congenital } & ASD & 789 & 405 \\
\cline { 2 - 4 } & VSD & 456 & 390 \\
\cline { 2 - 4 } & TOF (Total correction) & 358 & 33 \\
\cline { 2 - 4 } & BT shunt & 23 & 207 \\
\cline { 2 - 4 } & PDA & 165 & 1221 \\
\hline
\end{tabular}

CABG, Coronary artery bypass graft; Valve, Valvular surgery; ASD, Atrial septal defect; VSD, Ventricular septal defect; MVR, Mitral valve replacement; AVR, Aortic valve replacement; DVR, Double valve replacement; TOF, Tetralogy of Fallot; BT, Blalock-Taussig shunt; PDA, Patent ductus arteriosus. 
the cardiac interventions done is under construction on behalf of the Bangladesh Cardiac Society.

Data available from NICVD and the registry maintained by BACTA are being presented here. (Table 5 to 8 )

Besides curative services, there are some efforts to ensure preventive and promotive services.

In the current Health, Population and Nutrition Sector Development Program (HPNSDP) 2011-2016, control of NCDs, including CVDs is one of the topmost priority areas of healthcare in the country. ${ }^{10}$ Government has formulated National NCD Strategy and plan of action. Different nonGovernment organizations, including $\mathrm{WHO}$ are playing important role in this regard as well.

\section{The BRAVE [Bangladesh Risk of Acute Vascular Events] study}

Despite the enormous magnitude of CVD in Bangladesh, the volume and quality of research related to this issue is limited. Also, many aspects of CVD in Bangladesh, including the undue prevalence of CAD in this population, are unknown. The Bangladesh Risk of Acute Vascular Events (BRAVE) study is an epidemiological bioresource established to examine environmental, genetic, lifestyle and biochemical determinants of CAD among the Bangladeshi population. ${ }^{64}$ This study is a joint collaboration of Cambridge University of UK, International Centre for Diarrhoeal Disease Research, Bangladesh (ICDDRB) and the NICVD in Dhaka of Bangladesh. The study was established in 2011 by the Department of Public Health and Primary Care at the University of Cambridge (the study's international coordinating centre), in collaboration with the Chronic NCD Unit at ICDDRB and at NICVD in Bangladesh. By early 2015, the ongoing BRAVE study had recruited over 5000 confirmed first-ever myocardial infarction cases, and over 5000 controls "frequency-matched" by age and sex. Initial analyses indicate that Bangladeshis are genetically distinct from major non-South Asian ethnicities, as well as distinct from other South Asian ethnicities. Also, several environmental contaminants (e.g. arsenic in the blood) and nutritional elements (e.g. zinc deficiency) are emerging as important drivers for heart attacks in this population.

DNA genotyping data of 5755 subjects of the BRAVE study have been used in a recent study also involving the participants of the PROMIS study, and the participants belonging to the European ancestry. ${ }^{147}$ The study demonstrates that carriers of loss-of-function mutations in ANGPTL4 gene had triglyceride levels that were lower than those among noncarriers; these mutations were also associated with protection from CAD.

\section{Future Directions}

Data related to different aspects of CVD in Bangladesh are inadequate. Large, preferably nationwide epidemiological and clinical studies should be carried out to gain reliable information on this important public health issue. CVD prevention should be integrated with primary health care. Cardiovascular health promotion should be part of the national media strategy and the health education curriculum. The public health approach should target population-wide lifestyle intervention, screening for high blood pressure, diabetes and dyslipidaemia. Healthy lifestyles including consumption of heart-healthy diets, avoidance to smoking and smokeless tobacco, moderation of salt intake and increased physical activity, should be promoted. Limitations can be placed on the concentrations of salt, sugar, trans-fats and saturated fats in manufactured food products. Food labeling should also be introduced to facilitate informed choice by consumers. Food adulteration should be dealt rigorously. Provision of safe, arsenic-free water and food should be ensured. Necessary legislative and administrative steps should be taken to reduce air pollution. Policy change should address urban planning, transport and preservation of environment. Special attention should be given to stop malnutrition and under nutrition in fetal and neonatal life through nutrition programmes. Public awareness should be created to avoid childhood obesity. If indicated by further research, vitamin $\mathrm{D}$ deficiency may be avoided by fortification of food. Further research, may be in collaboration with international organizations, should be undertaken to explore the still-unidentified risk factors of CVD unique to this nation.

Renovation of National Centre for Control of Rheumatic Fever and Heart Diseases (NCCRF\&HD) may be done to boost up research in RF and chronic RHD and render point-of-care services involving medical, interventional, as well as, surgical modalities of treatment. Appropriate guidelines should be formulated in relation to RHD to bring about uniformity and rationality in existing practice.

\section{Conclusion:}

CVD is a major public health burden in Bangladesh. Besides the well-known risk factors, genetic factors and some emerging risk factors unique to this population may play an important role in CVD. At the advent of the new millennium, more and more information is becoming available; however, presumably much is still unknown. 
We have no more time to lapse. Large-scale, preferably, nation-wide survey and clinical research should be conducted to determine the different aspects of CAD in Bangladesh. The information available hereby, would help to formulate national policy to combat the deadly epidemic more efficiently in future. This information would be used to formulate national cardiovascular guidelines for early detection and prevention of CVD with top importance.

\section{References:}

1. Karar ZA, Alam N, Streatfield K. Epidemiological transition in rural Bangladesh, 1986-2006. Glob Health Action. 2009;2(Supplements):1-9.

2. Omran AR. The epidemiological transition: a theory of the epidemiology of population change. Milbank Memorial Fund Quarterly. 1971;49:509-38.

3. Bleich SN, Koehlmoos TLP, Rashid M, MPH, Peters $\mathrm{DH}$, Anderson G. Noncommunicable chronic disease in Bangladesh: Overview of existing programs and priorities going forward. Health Policy. 2011 May; 100(2-3): 282-289. Published online 2010 Oct 23.

4. World Health Organization - Noncommunicable Diseases (NCD) Country Profiles, 2014. Bangladesh. Available at: http://apps.who.int/iris/ bitstream/10665/128038/1/9789241507509_ eng.pdf?ua=1, accessed 14 Dec 2016.

5. World Health Organization. Cardiovascular diseases (CVDs). Fact sheet $\mathrm{N}^{\circ} 317$. Updated January 2015. Available at: http://www.who.int/ mediacentre/factsheets/fs317/en/.

6. Mozaffarian D, Benjamin EJ, Go AS, Arnett DK, Blaha MJ, Cushman M, et al. Heart Disease and Stroke Statistics-2016 Update: A Report From the American Heart Association. Circulation.2015 Dec 16.pii: CIR.0000000000000350.

7. Gupta R, Joshi P, Mohan V, Reddy KS, Yusuf S. Epidemiology and causation of coronary heart disease and stroke in India. Heart. 2008 Jan;94(1):16-26.

8. Gupta R, Gupta KD. Coronary heart disease in low socioeconomic status subjects in India: "an evolving epidemic". Indian Heart J. 2009 JulAug;61(4):358-67.

9. Sample Registration System. Office of the Registrar General and Census Commissioner, India under
Ministry of Home Affairs, Government of India.http:/ /www.censusindia.gov.in/2011-common/ Sample_Registration_System.html, accessed 06 Feb 2016.

10. Health Bulletin 2015. Directorate General of Health Services. Ministry of Health and Family Welfare, Government of the People's Republic of Bangladesh. Available at: http://www.dghs.gov.bd/ i m a g e s/d o c s/ P u b I i c a a t i o n s / HB\%202015_1st_edition_31122015.pdf, accessed, 14 Dec 2016.

11. Malik A. Congenital and acquired heart diseases: (A survey of 7062 persons). Bangladesh Med Res Counc Bull. 1976 Dec;2(2):115-9.

12. Van Minh $\mathrm{H}, \mathrm{Ng} \mathrm{N}$, Juvekar $\mathrm{S}$, Razzaque $\mathrm{A}$, Ashraf $\mathrm{A}$, Hadi $A$, et al. Self-reported prevalence of chronic diseases and their relation to selected sociodemographic variables: a study in INDEPTH Asian sites, 2005. Prev Chronic Dis. 2008 Jul;5(3):A86.

13. Zaman MM, Ahmed J, Choudhury SR, Numan SM, Parvin K, Islam MS. Prevalence of ischemic heart disease in a rural population of Bangladesh. Indian Heart J. 2007 May-Jun;59(3):239-41.

14. Ahsan SA, Haque KS, Salman M, Bari AS, Nahar H, Ahmed MK, et al. Detection of ischaemic heart disease with risk factors in different categories of employees of University Grants Commission. University Heart Journal. 2009;5(1):20-3.

15. Sayeed MA, Mahtab H, Sayeed S, Begum T, Khanam PA, Banu A. Prevalence and risk factors of coronary heart disease in a rural population of Bangladesh. Ibrahim Medical College Journal. 2010;4(2):37-43.

16. Parr JD, Lindeboom W, Khanam MA, Pérez Koehlmoos TL. Diagnosis of chronic conditions with modifiable lifestyle risk factors in selected urban and rural areas of Bangladesh and sociodemographic variability therein. BMC Health Serv Res. 2011 Nov 11;11:309.

17. Islam AKMM, Majumder AAS. Coronary artery disease in Bangladesh: a review. Indian Heart J. 2013 Jul-Aug;65(4):424-35.

18. Ullah W. Hypertension in a mixed community.Bangladesh Med Res Counc Bull. 1976 Dec;2(2):95-9.

19. Islam N, Khan M, Latif ZA. Hypertension in the rural population of Bangladesh-a preliminary 
survey.Bangladesh Med Res Counc Bull. 1983 Jun;9(1):11-4.

20. Sayeed MA, Khan AR, Banu A, Hussain MZ, Ali SM. Blood pressure and glycemic status in relation to body mass index in a rural population of Bangladesh. Bangladesh Med Res Counc Bull. 1994 Aug;20(2):27-35.

21. Sayeed MA, Banu A, Haq JA, Khanam PA, Mahtab $\mathrm{H}$, Azad Khan AK. Prevalence of hypertension in Bangladesh: effect of socioeconomic risk factor on difference between rural and urban community. Bangladesh Med Res Counc Bull. 2002 Apr;28(1):7-18.

22. Sayeed MA, Mahtab H, AkterKhanam P, Abdul Latif Z, Keramat Ali SM, Banu A, et al. Diabetes and impaired fasting glycemia in a rural population of Bangladesh. Diabetes Care. 2003 Apr;26(4):1034-9.

23. Zaman MM, Choudhury SR, Ahmed J, Numan SM, Islam MS, Yoshiike N. Non-biochemical risk factors for cardiovascular disease in general clinic-based rural population of Bangladesh. J Epidemiol. 2004 Mar;14(2):63-8.

24. Chen Y, Factor-Litvak P, Howe GR, Parvez F, Ahsan $\mathrm{H}$. Nutritional influence on risk of high blood pressure in Bangladesh: a population-based cross-sectional study. Am J Clin Nutr. 2006 Nov;84(5):1224-32.

25. Rahim MA, Hussain A, Azad Khan AK, Sayeed MA, Keramat Ali SM, Vaaler S. Rising prevalence of type 2 diabetes in rural Bangladesh: a population based study. Diabetes Res ClinPract. 2007 Aug;77(2):3005. Epub 2006 Dec 20.

26. Al Mamun M, Rumana N, Pervin K, Azad MC, Shahana N, Choudhury SR, et al. Emerging Burden of Cardiovascular Diseases in Bangladesh. J Atheroscler Thromb. 2016;23(4):365-75.

27. World Health Organization. Non-communicable disease risk factor survey, Bangladesh 2010. Available at: http://www.who.int/chp/steps/ 2010_STEPS_Report_Bangladesh.pdf. Accessed 20 Dec 2016.

28. Cravedi P, Sharma SK, Bravo RF, Islam N, Tchokhonelidze I, Ghimire M, et al. Preventing renal and cardiovascular risk by renal function assessment: insights from a cross-sectional study in low-income countries and the USA. BMJ Open. 2012 Sep 22;2(5).
29. Rahman MM, Gilmour S, Akter S, Abe SK, Saito E, Shibuya K. Prevalence and control of hypertension in Bangladesh: a multilevel analysis of a nationwide population-based survey. J Hypertens. 2015 Mar;33(3):465-72; discussion 472.

30. Bhowmik B, Afsana F, My Diep L, Binte Munir S, Wright E, Mahmood S, et al. Response: increasing prevalence of type 2 diabetes in a rural bangladeshi population: a population based study for 10 years (diabetes metab j 2013;37:46-53). Diabetes Metab J. 2013 Apr;37(2):153-4.

31. Neupane D, McLachlan CS, Sharma R, Gyawali B, Khanal V, Mishra SR, et al. Prevalence of hypertension in member countries of South Asian Association for Regional Cooperation (SAARC): systematic review and meta-analysis. Medicine (Baltimore). 2014 Sep;93(13):e74.

32. Khanam MA, Lindeboom W, Razzaque A, Niessen $\mathrm{L}$, Milton AH. Prevalence and determinants of prehypertension and hypertension among the adults in rural Bangladesh: findings from a communitybased study. BMC Public Health. 2015 Feb 28;15:203.

33. Islam FM, Bhuiyan A, Chakrabarti R, Rahman MA, Kanagasingam $Y$, Hiller JE. Undiagnosed hypertension in a rural district in Bangladesh: The Bangladesh Population-based Diabetes and Eye Study (BPDES). J Hum Hypertens. 2016 Apr;30(4):252-9.

34. Fatema K, Zwar NA, Milton AH, Ali L, Rahman B. Prevalence of Risk Factors for Cardiovascular Diseases in Bangladesh: A Systematic Review and Meta-Analysis. PLoS One. 2016 Aug 5;11(8):e0160180.

35. Islam AKMM, Majumder AA. Hypertension in Bangladesh: a review. Indian Heart J. 2012 MayJun;64(3):319-23.

36. Ahmed J, Zaman M, Hassan MM. Prevalence of rheumatic fever and rheumatic heart disease in rural Bangladesh. Trop Doct. 2005 Jul;35(3):1601.

37. Haque KMHSS, Hossain M, Mahmud RS, et al. Epidemiology of rheumatic fever and rheumatic heart disease: Observations in 15798 children of rural and urban areas. In: Faruq QO. (ed.) Proceedings of First National Scientific Conference on Rheumatic Fever and Rheumatic Heart Disease, May 4-5, 1992, Dhaka, Bangladesh. Dhaka: Ministry 
of Health and Family Welfare, Government of the People's Republic of Bangladesh and Japan International Cooperation Agency (JICA), Government of Japan; 1992.

38. Banoo H, Rahman S, Alam A, Azad AK, Sayeed A, Awwal A. Prevalence of rheumatic fever and rheumatic heart diseases in school children in Dhaka city. Bangladesh Med Res Counc Bull. 1987 Dec;13(2):92-100.

39. Mahmud RS, Hossain M, Mosud, et al. Prevalence of rheumatic fever and rheumatic heart diseases in 5-18 years school children of Dhaka city- A study of 5011 school children. Chest \& Heart Bulletin 1992;16(1):15-22.

40. Begum UHN, Haque KMHSS, Hossain M, Amanullah M, Zafar A. Prevalence of rheumatic fever and rheumatic heart diseases in the Dhaka city, Bangladesh. Bangladesh Heart Journal 1994;9(1):4-8.

41. Majumder AAS, Flora MS, Shahidullah M, et al. Prevalence of rheumatic fever and rheumatic heart disease in school children of Bharateswari Homes of Bangladesh. Cardiovascular Journal 2014;6 (2):103-6.

42. Zaman MM, Choudhury SR, Rahman S, Ahmed J. Prevalence of rheumatic fever and rheumatic heart disease in Bangladeshi children. Indian Heart $\mathrm{J}$. 2015 Jan-Feb;67(1):45-9.

43. Islam AKMM, Majumder AA. Rheumatic fever and rheumatic heart disease in Bangladesh: A review. Indian Heart J. 2016 May-Jun;64(3):319-23.

44. Kabiruzzaman M, Malik FM, Ahmed N, et al. Burden of heart failure patients in a tertiary level cardiac hospital. Journal of Bangladesh College of Physicians and Surgeons, [S.I.], v. 28, n. 1, p. 2429, Mar. 2010. ISSN 1015-0870. Available at: <http:/ /www.banglajol.info/index.php/JBCPS/article/view/ 4640>. Date accessed: 16 Mar. 2016. doi:http:// dx.doi.org/10.3329/jbcps.v28i1.4640.

45. Muhit MA, Rahman MO, Raihan SZ, et al. Journal of Applied Pharmaceutical Science 2012;02(03):804.

46. Fatema NN, Chowdhury RB, Chowdhury L. Incidence of congenital heart disease among hospital live birth in a tertiary hospital of Bangladesh. Cardiovascular Journal 2008;1(1):14-20.
47. Hussain M, Tahura S, Sayeed MA et al. Past and present pattern of congenital heart disease at Dhaka Shishu Hospital: A situation analysis. Bangladesh J Child Health 2010; 34(2):51-5.

48. Sharmin LS, Haque MA, Bari MI et al. Pattern \& clinical profile of congenital heart disease in a teaching hospital. The Journal of Teachers Association RMC, Rajshahi 2008; 21(2):58-62.

49. Rezwan MS. Congenital heart diseases among the hospital live birth in Bangladesh: A retrospective study in a tertiary medical college hospital. 4th International Conference on Clinical \& Experimental Cardiology April 14-16, 2014 Hilton San Antonio Airport, USA. Available at: http:// www.omicsonline.org/abstract/congenital-heartdiseases-among-the-hospital-live-birth-inbangladesh-a-retrospective-study-in-a-tertiarymedical-college-hospital/, accessed 16 Mar 2016.

50. Mohammad QD, Habib M, Hoque A, Alam B, Haque $B$, Hossain S, et al. Prevalence of stroke above forty years. Mymensingh Med J. 2011 Oct;20(4):640-4.

51. Zaman MM, Choudhury SR, Ahmed J, Hussain SM, Sobhan SM, Turin TC. Prevalence of Stroke in a Rural Population of Bangladesh. Glob Heart. 2015 Dec;10(4):333-4.

52. Yusuf S, Reddy S, Ounpuu S, Anand S. Global burden of cardiovascular diseases: Part II: variations in cardiovascular disease by specific ethnic groups and geographic regions and prevention strategies. Circulation. 2001 Dec;104(23):2855-64.

53. Palaniappan LP, Araneta MR, Assimes TL, BarrettConnor EL, Carnethon MR, Criqui MH, et al. Call to action: cardiovascular disease in Asian Americans: a science advisory from the American Heart Association. Circulation. 2010 Sep;122(12):124252.

54. Enas EA, Garg A, Davidson MA, Nair VM, Huet BA, Yusuf $S$. Coronary heart disease and its risk factors in first-generation immigrant Asian Indians to the United States of America. Indian Heart J. 19961996 Jul-Aug;48(4):343-53.

55. Gupta M, Singh N, Verma S. South Asians and cardiovascular risk: what clinicians should know. Circulation. 2006 Jun;113(25):e924-9.

56. Gupta M, Doobay AV, Singh N, Anand SS, Raja F, Mawji F, et al. Risk factors, hospital management 
and outcomes after acute myocardial infarction in South Asian Canadians and matched control subjects. CMAJ. 2002 Mar;166(6):717-22.

57. London Life Sciences Prospective Population Study. http://www.lolipopstudy.org.Accessed 8 April 2015.

58. Saleheen D, Zaidi M, Rasheed A, Ahmad U, Hakeem A, Murtaza M, et al. The Pakistan Risk of Myocardial Infarction Study: a resource for the study of genetic, lifestyle and other determinants of myocardial infarction in South Asia. Eur J Epidemiol. 2009;24(6):329-38.

59. IBC $50 \mathrm{~K}$ CAD Consortium. Large-scale genecentric analysis identifies novel variants for coronary artery disease. PLoS Genet. 2011;7(9):e1002260.

60. Coronary Artery Disease (C4D) Genetics Consortium. A genome-wide association study in Europeans and South Asians identifies five new loci for coronary artery disease. Nat Genet. 2011;43(4):339-344.

61. Saxena R, Saleheen D, Been LF, Garavito ML, Braun T, Bjonnes A, et al. Genome-wide association study identifies a novel locus contributing to type 2 diabetes susceptibility in Sikhs of Punjabi origin from India. Diabetes. 2013;62(5):1746-1755.

62. Kooner JS, Saleheen D, Sim X, Sehmi J, Zhang W, Frossard P, et al. Genome-wide association study in individuals of South Asian ancestry identifies six new type 2 diabetes susceptibility loci. Nat Genet. 2011;43(10):984-989.

63. Saxena R, Elbers CC, Guo Y, Peter I, Gaunt TR, Mega JL, et al. Large-scale gene-centric metaanalysis across 39 studies identifies type 2 diabetes loci. Am J Hum Genet. 2012;90(3):410-425.

64. Chowdhury R, Alam DS, Fakir II, Adnan SD, Naheed A, Tasmin I, et al. The Bangladesh Risk of Acute Vascular Events (BRAVE) Study: objectives and design. Eur J Epidemiol. 2015 Jul;30(7):577-87.

65. Chowdhury AH, Zaman MM, Haque KM, Rouf MA, Shah AT, Nakayama T, et al. Association of angiotensin converting enzyme (ACE) gene polymorphism with hypertension in a Bangladeshi population. Bangladesh Med Res Counc Bull. 1998 Dec;24(3):55-9.

66. Morshed M, Khan H, Akhteruzzaman S. Association between angiotensin I converting enzyme gene polymorphism and hypertension in selected individuals of the Bangladeshi population. $J$ Biochem Mol Biol. 2002;35(3):251-4.
67. Akter S, Rahman MM, Abe SK, Sultana P. Prevalence of diabetes and prediabetes and their risk factors among Bangladeshi adults: a nationwide survey. Bull World Health Organ. 2014 Mar 1;92(3):204-13, 213A.

68. Rahman MS, Akter S, Abe SK, Islam MR, Mondal MN, Rahman JA, et al. Awareness, treatment, and control of diabetes in Bangladesh: a nationwide population-based study. PLoS One. 2015 Feb 18;10(2):e0118365.

69. Biswas T, Islam A, Rawal LB, Islam SM. Increasing prevalence of diabetes in Bangladesh: a scoping review. Public Health. 2016 Sep;138:4-11.

70. Whiting DR, Guariguata L, Weil C, Shaw J. IDF diabetes atlas: global estimates of the prevalence of diabetes for 2011 and 2030. Diabetes Res Clin Pract. 2011 Dec;94(3):311-21.

71. Hanifi SA, Mahmood SS, Bhuiya A. Smoking has declined but not for all: Findings from a study in a rural area of Bangladesh. Asia Pac J Public Health. May 242010.

72. Palipudi K, Rizwan SA, Sinha DN, Andes LJ, Amarchand R, Krishnan A, et al. Prevalence and sociodemographic determinants of tobacco use in four countries of the World Health Organization: South-East Asia region: findings from the Global Adult Tobacco Survey. Indian J Cancer. 2014 Dec;51Suppl 1:S24-32.

73. Nargis N, Thompson ME, Fong GT, Driezen P, Hussain AK, Ruthbah UH, et al. Prevalence and Patterns of Tobacco Use in Bangladesh from 2009 to 2012: Evidence from International Tobacco Control (ITC) Study. PLoS One. 2015 Nov 11;10(11):e0141135.

74. Alam DS, Jha P, Ramasundarahettige C, Streatfield PK, Niessen LW, Chowdhury MA, et al. Smokingattributable mortality in Bangladesh: proportional mortality study. Bull World Health Organ. 2013 Oct 1;91(10):757-64.

75. Rahman MA, Mahmood MA, Spurrier N, Rahman M, Leeder S. A systematic review of epidemiological studies on the association between smokeless tobacco use and coronary heart disease. J. Public Health Epidemiol. 2011;3(12):593-603.

76. Enas EA, Chacko V, Pazhoor SG, Chennikkara H, Devarapalli HP. Dyslipidemia in South Asian patients. Curr Atheroscler Rep. 2007 Nov;9(5): 367-74. 
77. Karthikeyan G, Teo KK, Islam S, McQueen MJ, Pais $P$, Wang $X$, et al. Lipid profile, plasma apolipoproteins, and risk of a first myocardial infarction among Asians: An analysis from the INTERHEART Study. J Am Coll Cardiol. 2009 Jan 20;53(3):244-53.

78. Enas EA, Senthilkumar A, Chennikkara H, Bjurlin MA. Prudent diet and preventive nutrition from pediatrics to geriatrics: current knowledge and practical recommendations. Indian Heart J 2003, 55:310-38.

79. Das SK, Golam Faruque AS, Chowdhury AK, Chisti MJ, Hossain MA, Salam MA, et al. Lipoprotein status among urban populations in Bangladesh. Atherosclerosis. 2012 Aug;223(2):454-7.

80. Islam N, Rahman MZ, Choudhury S, Afrin L, Rahman S, Aftabuddin M. Prevalence of dyslipidaemia and associated factors among the suburban Bangladeshi population. University Heart Journal 2012;8(1):15-9.

81. Zaman M, Choudhury SR, Ahmed J, Yoshiike N, Numan SM, Islam M MS, et al. Plasma lipids in a rural population of Bangladesh. Eur J Cardiovasc Prev Rehabil. 2006 Jun;13(3):444-8.

82. Siddiquee $\mathrm{T}$, Bhowmik $\mathrm{B}, \mathrm{Da}$ Vale Moreira NC, Mujumder A, Mahtab H, Khan AK, et al. Prevalence of obesity in a rural Asian Indian (Bangladeshi) population and its determinants. BMC Public Health. 2015 Sep 4;15:860.

83. Khan RJ, Harvey DJ, Leistikow BN, Haque KS, Stewart CP. Relationship between obesity and coronary heart disease among urban Bangladeshi men and women. Integr Obes Diabetes. 2015 May;1(3):49-55.

84. Rahman S, Islam MT, Alam DS. Obesity and overweight in Bangladeshi children and adolescents: a scoping review. BMC Public Health. 2014 Jan 22;14:70.

85. Bulbul T, Hoque M. Prevalence of childhood obesity and overweight in Bangladesh: findings from a countrywide epidemiological study. BMC Pediatr. 2014 Apr 1;14:86.

86. Zabeen B, Tayyeb S, Naz F, Ahmed F, Rahman M, Nahar J, et al. Prevalence of obesity and central obesity among adolescent girls in a district school in Bangladesh. Indian J Endocrinol Metab. 2015 Sep-Oct;19(5):649-52.
87. Bhowmik B, Afsana F, Siddiquee T, Munir SB, Sheikh $F$, Wright E, et al. Comparison of the prevalence of metabolic syndrome and its association with diabetes and cardiovascular disease in the rural population of Bangladesh using the modified National Cholesterol Education Program Expert Panel Adult Treatment Panel III and International Diabetes Federation definitions. J Diabetes Investig. 2015 May;6(3):280-8.

88. Rahim MA, Khan AKA, Sayeed MA, Akhtar B, Nahar $\mathrm{Q}$, Ali SMK, et al. Metabolic syndrome in rural Bangladesh: Comparison of newly proposed IDF, modiûed ATP III and WHO criteria and their agreements. Diabetes \& Metabolic Syndrome: Clinical Research \& Reviews. 2007;1:251-7.

89. Khanam MA, Qiu C, Lindeboom W, Streatfield PK, Kabir ZN, Wahlin A. The metabolic syndrome: Prevalence, associated factors, and impact on survival among older persons in rural Bangladesh. PLoS ONE 6(6): e20259.

90. Jesmin S, Mia S, Islam AM, Islam R, Sultana SN, Zaedi $S$, et al. Prevalence of metabolic syndrome among rural Bangladeshi women. Diabetes Res Clin Pract. 2012 Jan;95(1):e7-9.

91. Chen Y, McClintock TR, Segers S, Parvez F, Islam T, Ahmed A, et al. Prospective investigation of major dietary patterns and risk of cardiovascular mortality in Bangladesh. Int J Cardiol. 2013 Aug 20;167(4):1495-501.

92. Jiang J, Liu M, Parvez F, Wang B, Wu F, Eunus M, et al. Association of major dietary patterns and blood pressure longitudinal change in Bangladesh. J Hypertens. 2015 Jun;33(6):1193-200.

93. Chen Y, Factor-Litvak P, Howe GR, Parvez F, Ahsan $\mathrm{H}$. Nutritional influence on risk of high blood pressure in Bangladesh: a population-based cross-sectional study. Am J Clin Nutr. 2006 Nov;84(5):1224-32.

94. McClintock TR, Parvez F, Wu F, Islam T, Ahmed A, Rani Paul R, et al. Major dietary patterns and carotid intima-media thickness in Bangladesh. Public Health Nutr. 2016 Feb;19(2):218-29.

95. Food-based nutrition strategies in Bangladesh. Food and Agriculture Organization. Regional Office for Asia and the Pacific. Available at: http:// www.fao.org/docrep/010/ag126e/AG126E05.htm.

96. FAO/WHO. 2003. Diet, nutrition and the prevention of chronic diseases. Report of a joint FAO/WHO. 
Expert Consultation. WHO Technical Report Series 916. Geneva. World Health Organization.

97. Penney S. Dropping the salt: Practical steps countries are taking to prevent chronic noncommunicable diseases through population-wide dietary salt reduction. The Public Health Agency of Canada (PHAC). Revised version: February 2009.

98. Salt consumption in hypertensive patients attending in a tertiary level cardiac hospital. http:// www.worldactiononsalt.com/awareness/ world_salt_awareness_week_2008/evaluation/ bangladesh_paper.doc.

99. World Health Organization. Diet, Nutrition and the Prevention of Chronic Diseases. Report of a Joint WHO/FAO Expert Consultation. WHO Technical Report Series No. 916. Geneva: World Health Organization, 2003.

100. U.S. Department of Health and Human Services and U.S. Department of Agriculture. 2015-2020 Dietary Guidelines for Americans. 8th Edition. December 2015. Available at http://health.gov/ dietaryguidelines/2015/guidelines/ .Accessed September 17, 2016.

101. Islam SM, Mainuddin A, Islam MS, Karim MA, Mou SZ, Arefin S, et al. Prevalence of risk factors for hypertension: A cross-sectional study in an urban area of Bangladesh. Glob Cardiol Sci Pract. 2015 Nov 20;2015(4):43.

102. Talukder MR, Rutherford S, Phung D, Islam MZ, Chu C. The effect of drinking water salinity on blood pressure in young adults of coastal Bangladesh. Environ Pollut. 2016 Jul;214:248-54.

103. Rasheed S, Siddique AK, Sharmin T, Hasan AM, Hanifi SM, Iqbal M, et al. Salt intake and health risk in climate change vulnerable coastal Bangladesh: What role do beliefs and practices play? PLoS One. 2016 Apr 4;11(4):e0152783.

104. Zhang Z, Kris-Etherton PM, Hartman TJ. Birth weight and risk factors for cardiovascular disease and type 2 diabetes in US children and adolescents: 10 year results from NHANES. Matern Child Health J. 2014 Aug;18(6):1423-32.

105. Risnes KR, Vatten LJ, Baker JL, Jameson K, Sovio $U$, Kajantie E, et al. Birth-weight and mortality in adulthood: a systematic review and meta-analysis. Int J Epidemiol. 2011 Jun;40(3):647-61.
106. Joss-Moore LA, Lane RH. Perinatal nutrition, epigenetics, and disease. Curr Opin Pediatr. 2009 Apr;21(2):230-4.

107. Haas GM, Liepold E, Schwandt P. Low birth weight as a predictor of cardiovascular risk factors in childhood and adolescence? The PEP Family Heart Study. Int J Prev Med. 2015 Dec 21;6:121.

108. National Low Birth Weight Survey of Bangladesh, 2003-2004. Bangladesh Bureau of Statistics, Planning Division, Ministry of Planning, Government of the People's Republic of Bangladesh. September 2005.

109. van Abeelen AF, Elias SG, Bossuyt PM, Grobbee DE, van der Schouw YT, Roseboom TJ, et al. Cardiovascular consequences of famine in the young. Eur Heart J. 2012 Feb;33(4):538-45.

110. JamshidiY, Gibson P, Ray KK. Under-nutrition in adolescence and risk of cardiovascular disease. Eur Heart J. 2012 Feb;33(4):433-5.

111. Food and Agriculture Organization of the United Nations. Agriculture and Consumer Protection Department. Nutrition country profiles: Bangladesh. Available at: http://www.fao.org/ag/agn/nutrition/ bgd_en.stm, accessed on March 6, 2016.

112. Alom J, Quddus MA, Islam MA. Nutritional status of under-five children in Bangladesh: a multilevel analysis. J Biosoc Sci. 2012 Sep;44(5):525-35.

113. Ruiter L, Shi J, Papp E, Mahmud AA, Gernand A, Roth D. Vitamin D status of husbands of pregnant women in Dhaka, Bangladesh. FASEB J. 2016;30:1(sup 892.8)

114. Roth DE, Shah MR, Black RE, Baqui AH. Vitamin D status of infants in northeastern rural Bangladesh: preliminary observations and a review of potential determinants. J Health Popul Nutr. 2010 Oct;28(5):458-69.

115. Islam MZ, Lamberg-Allardt C, Kärkkäinen M, Outila T, Salamatullah Q, Shamim AA. Vitamin D deficiency: A concern in premenopausal Bangladeshi women of two socio-economic groups in rural and urban region. Eur J ClinNutr 2002;56(1):51-6.

116. Islam MZ, Akhtaruzzaman M, Lamberg-Allardt $\mathrm{C}$. Hypovitaminosis $D$ is common in both veiled and non-veiled Bangladeshi women. Asia Pac J Clin Nutr 2006;15(1):81-7.

117. Wu F, Jasmine F, Kibriya MG, Liu M, Cheng X, Parvez $F$, et al. Interaction between arsenic exposure from 
drinking water and genetic polymorphisms on cardiovascular disease in Bangladesh: a prospective case-cohort study. Environ Health Perspect. 2015 May;123(5):451-7.

118. Islam MS, Mohanto NC, Karim MR, Aktar S, Hoque MM, Rahman A, et al. Elevated concentrations of serum matrix metalloproteinase-2 and -9 and their associations with circulating markers of cardiovascular diseases in chronic arsenicexposed individuals. Environ Health. 2015 Dec 4;14:92.

119. Wu F, Jasmine F, Kibriya MG, Liu M, Cheng X, Parvez $F$, et al. Interaction between arsenic exposure from drinking water and genetic susceptibility in carotid intima-media thickness in Bangladesh. Toxicol Appl Pharmacol. 2014 May 1;276(3):195-203.

120. Chen Y, Wu F, Liu M, Parvez F, Slavkovich V, Eunus $M$, et al. A prospective study of arsenic exposure, arsenic methylation capacity, and risk of cardiovascular disease in Bangladesh. Environ Health Perspect. 2013 Jul;121(7):832-8.

121. Ahmad SA, Khatun F, Sayed MH, Khan MH, Aziz R, Hossain MZ, et al. Electrocardiographic abnormalities among arsenic-exposed persons through groundwater in Bangladesh. J Health PopulNutr. 2006 Jun;24(2):221-7.

122. Farzan SF, Karagas MR, Jiang J, Wu F, Liu M, Newman JD, et al. Gene-arsenic interaction in longitudinal changes of blood pressure: Findings from the Health Effects of Arsenic Longitudinal Study (HEALS) in Bangladesh. Toxicol Appl Pharmacol. 2015 Oct 1;288(1):95-105.

123. Rahman M, Sohel N, Yunus M, Chowdhury ME, Hore SK, Zaman K, et al. A prospective cohort study of stroke mortality and arsenic in drinking water in Bangladeshi adults. BMC Public Health. 2014 Feb 18;14:174.

124. Wu F, Jasmine F, Kibriya MG, Liu M, Wójcik O, Parvez $\mathrm{F}$, et al. Association between arsenic exposure from drinking water and plasma levels of cardiovascular markers. Am J Epidemiol. 2012 Jun 15;175(12):1252-61.

125. Rahman M, Tondel M, Ahmad SA, Chowdhury IA, Faruquee $\mathrm{MH}$, Axelson O. Hypertension and arsenic exposure in Bangladesh. Hypertension1999, 33:74-78

126. Chen Y, Factor-Litvak P, Howe GR, Graziano JH, Brandt-Rauf P, Parvez F, et al. Arsenic exposure from drinking water, dietary intakes of B vitamins and folate, and risk of high blood pressure in Bangladesh: A population-based, cross-sectional study. Am J Epidemiol 2007;165:541-52.

127. Chen Y, Graziano JH, Parvez F, Liu M, Slavkovich V, Kalra T, et al. Arsenic exposure from drinking water and mortality from cardiovascular disease in Bangladesh: Prospective cohort study. BMJ 2011;342:d2431doi:10.1136/bmj.d2431.

128. Brook RD, Rajagopalan S, Pope CA 3rd, Brook JR, Bhatnagar A, Diez-Roux AV, et al. Particulate matter air pollution and cardiovascular disease. An update to the scientific statement from the American Heart Association. Circulation. 2010;121:2331-78.

129. Rana MM, Sulaiman N, Sivertsen B, Khan MF, Nasreen S. Trends in atmospheric particulate matter in Dhaka, Bangladesh, and the vicinity. Environ Sci Pollut Res Int. 2016 Sep;23(17):17393-403.

130. Gurjar BR, Butler TM, Lawrence MG, Lelieveld J. Evaluation of emissions and air quality in megacities. Atmospheric Environment 2008;42:1593-1606. Available at: http://dx.doi.org/ 10.1016/j.atmosenv.2007.10.048.

131. Salam A, Mamoon HA, Ullah MB, Ullah SM. Measurement of the atmospheric aerosol particle size distribution in a highly polluted mega-city in Southeast Asia (Dhaka-Bangladesh). Atmospheric Environment 2012; 59; 33843. Available at: http:// dx.doi.org/10.1016/j.atmosenv.2012.05.024.

132. Begum BA, Kim E, Biswas SK, Hopke PK. Investigation of sources of atmospheric aerosol at urban and semi-urban areas in Bangladesh. Atmospheric Environment 2004;38(19):3025-38. Available at: http://dx.doi.org/10.1016/ j.atmosenv.2004.02.042.

133. Begum BA, Biswas SK, Kim E, Hopke PK, Khaliquzzaman $M$. Investigation of sources of atmospheric aerosol at a hot spot area in Dhaka, Bangladesh. J Air Waste Manag Assoc. 2005 Feb;55(2):227-40.

134. Begum BA, Biswas SK, Hopke PK. Key issues in controlling air pollutants in Dhaka, Bangladesh. Atmospheric Environment 2011;45(40):7705-13.

135. Begum BA, Paul SK, Hossain MD, Biswas SK, Philip K. Hopke PK. Indoor air pollution from particulate matter emissions in different households in rural areas of Bangladesh. Building and Environment. 2009;44(5):898-903. 
136. Alam DS, Chowdhury MA, Siddiquee AT, Ahmed S, Hossain MD, Pervin S, et al. Adult cardiopulmonary mortality and indoor air pollution: a 10-year retrospective cohort study in a low-income rural setting. Glob Heart. 2012 Sep;7(3):215-21.

137. Rahman S, Akanda MAK, Malik F, Ahmed N, Rahmatullah KHI. First experience with BARD-XT stent in Bangladesh for the treatment of acute occlusion PTCA. Bangladesh Heart Journal 1997;12(2):70-2.

138. Rahman S, Akanda MAK, Malik F, Ahmed N, et al. First successful intracoronary stent implantation at NICVD by Bangladeshi team- a case report. Bangladesh Journal of Medicine 1997;12(2):76-8.

139. Rahman S, Akanda MAK, Azam A, et al. Development of PTCA in Bangladesh: Clinical outcome of 10 months after attempted PTCA in 13 patients. Bangladesh Journal of Medicine 1997;8(1):8-12.

140. Khan NA, Alimuzzaman M, Rabbani G, et al. Closed mitral commissurotomy in juvenile mitral stenosis in Bangladesh. Bangladesh Heart Journal. 1987;2(2):73-6.

141. Ahmed NU, Khan SR, Ali M, Jalaluddin M. Closed mitral commissurotomy: Experience of 1500 cases in Bangladesh. Bangladesh Heart Journal. 1991 Jan;6(1):1-5.
142. Jamaluddin M, Khalil I, Karmakar KK, Kabir H, Litu $\mathrm{RI}$, Rashid B, et al. Outcomes of primary percutaneous coronary intervention (PCI) in NICVD, Dhaka, Bangladesh- our initial experiences. University Heart Journal 2013;9(2):83-7.

143. Chowdhury AHK, Uddin MS, Khalequzzaman M, Islam AKMM, Ali S, Roy US, et al. Primary percutaneous coronary intervention Experience in the National Institute of Cardiovascular Diseases, Dhaka. Journal of Cardiovascular Interventions. 2011;1:27-31.

144. Begum F, Khan KN, Momenuzzaman NAM, Sohail $\mathrm{KM}$, Haque SMZ, Shafique AM, et al. Primary angioplasty for the treatment of acute ST elevated myocardial infarction: Single centre experience. Cardiovascular Journal 2011;3(2):149-54.

145. Statistics of cardiac surgery in Bangladesh 2014. Bangladesh Journal of Cardiovascular and Thoracic Anaesthesiology 2015:2(1):38-9.

146. Statistics of cardiac surgery in Bangladesh 2015. Bangladesh Journal of Cardiovascular and Thoracic Anaesthesiology 2016:3(2):51-2.

147. Myocardial Infarction Genetics and CARDIoGRAM Exome Consortia Investigators, Stitziel NO, Stirrups KE, Masca NG, Erdmann J, Ferrario PG, König IR, et al. Coding variation in ANGPTL4, LPL, and SVEP1 and the risk of coronary disease. N Engl J Med. 2016 Mar 24;374(12):1134-44. 